\title{
Methane Cracking over Cobalt Molybdenum Carbides
}

\author{
I. Alshibane ${ }^{1} \mathbb{D} \cdot$ S. Laassiri ${ }^{1} \mathbb{D} \cdot$ J. L. Rico ${ }^{2}$ J. S. J. Hargreaves ${ }^{1} \mathbb{C}$
}

Received: 12 March 2018 / Accepted: 28 March 2018 / Published online: 21 April 2018

(c) The Author(s) 2018

\begin{abstract}
The catalytic behaviour of $\mathrm{Co}_{3} \mathrm{Mo}_{3} \mathrm{C}, \mathrm{Co}_{6} \mathrm{Mo}_{6} \mathrm{C}, \mathrm{Co}_{3} \mathrm{Mo}_{3} \mathrm{~N}$ and $\mathrm{Co}_{6} \mathrm{Mo}_{6} \mathrm{~N}$ for methane cracking has been studied to determine the relationship between the methane cracking activity and the chemical composition. The characterisation of post-reaction samples showed a complex phase composition with the presence of $\mathrm{Co}_{3} \mathrm{Mo}_{3} \mathrm{C}, \alpha-\mathrm{Co}$ and $\beta-\mathrm{Mo}_{2} \mathrm{C}$ as catalytic phases and the deposition of different forms of carbon during reaction.
\end{abstract}

\section{Graphical Abstract}

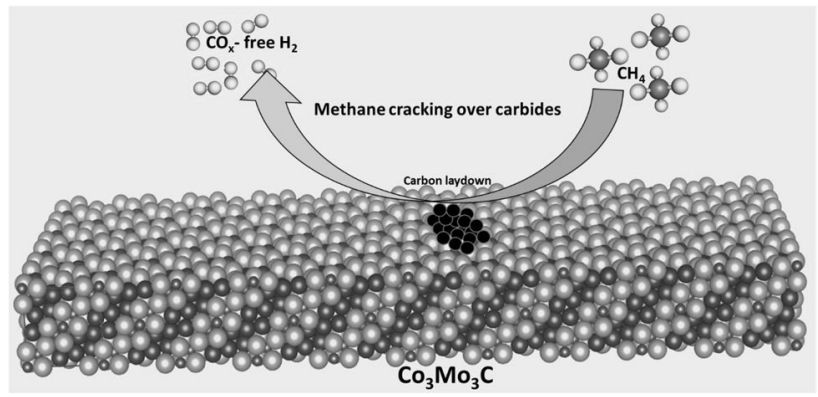

Keywords Methane cracking $\cdot$ Catalytic decomposition $\cdot$ Cobalt molybdenum carbide $\cdot$ Cobalt molybdenum nitride

Electronic supplementary material The online version of this article (https://doi.org/10.1007/s10562-018-2378-4) contains supplementary material, which is available to authorized users.

J. S. J. Hargreaves

Justin.Hargreaves@glasgow.ac.uk

I. Alshibane

I.alshibane.1@ research.gla.ac.uk

S. Laassiri

Said.Laassiri@glasgow.ac.uk

J. L. Rico

Jlceri@yahoo.com.mx

1 WestCHEM, School of Chemistry, University of Glasgow, Joseph Black Building, Glasgow G12 8QQ, UK

2 Laboratorio de Catálisis, Facultad de Ingeniería Química, Universidad Michoacana de San Nicolás de Hidalgo, Edif. V1, C.U., 58060 Morelia, Michoacán, Mexico

\section{Introduction}

The design of novel and efficient materials for catalytic reactions is of major interest. Although, many of the materials studied in heterogeneous catalysis are metal and metal oxide based, attention has been directed towards the development of entirely novel catalyst families that could display modified performance. Examples of the materials investigated include carbides, nitrides and boron alloys [1-3]. Amongst these materials, carbides have arguably received the most attention due to the perceived analogies between their behaviour and that of precious metals, suggesting them to be potential replacements. In this context, the presence of interstitial carbon species has been argued to modify the electronic properties of the parent metal in systems such as those based upon molybdenum or tungsten, making them akin to precious metals such as platinum $[4,5]$.

Within the literature, metal carbides are known to possess activity for a wide range of applications including 
Fischer-Tropsch processes [6-8], hydrogenation [9-11], dehydroaromatisation [12], oxygen and hydrogen evolution [13] and ammonia decomposition [14, 15]. In more recent work, the reactivity of cobalt molybdenum carbide was studied for ammonia synthesis to gain an enhanced understanding of the potential role of lattice composition (i.e. the influence of the presence of interstitial carbon versus interstitial nitrogen) upon catalytic activity [16]. Although $\mathrm{Co}_{3} \mathrm{Mo}_{3} \mathrm{C}$ was found to be active for ammonia synthesis, the material was only active at higher temperature $\left(500{ }^{\circ} \mathrm{C}\right)$ compared to its nitride counterpart which is active at $400{ }^{\circ} \mathrm{C}$, and such activity was associated with the presence of some lattice nitrogen residing in 16c Wyckoff sites as determined from in-situ neutron diffraction studies.

In the current manuscript, comparison is made between the performance of $\mathrm{Co}_{3} \mathrm{Mo}_{3} \mathrm{C}$ and $\mathrm{Co}_{6} \mathrm{Mo}_{6} \mathrm{C}$ for methane cracking to determine the role of stoichiometry and such performance is contrasted with their isostructural nitride counterparts. The methane cracking reaction is of potential interest as an environmentally friendly approach for $\mathrm{CO}_{\mathrm{x}}$-free hydrogen production [17-19].

\section{Experimental}

\subsection{Materials Preparation}

The preparation of cobalt molybdenum related materials has been documented in detail in our previous work $[16,20]$. In a typical synthesis, $\mathrm{CoMoO}_{4}$ was prepared by adding $5.59 \mathrm{~g}$ of $\mathrm{Co}\left(\mathrm{NO}_{3}\right)_{2} \cdot 6 \mathrm{H}_{2} \mathrm{O}(>98 \%$, Sigma-Aldrich) and $4.00 \mathrm{~g}$ of $\left(\mathrm{NH}_{4}\right)_{6} \mathrm{Mo}_{7} \mathrm{O}_{24} \cdot 4 \mathrm{H}_{2} \mathrm{O}(99.98 \%$, Sigma-Aldrich) dissolved in $200 \mathrm{~mL}$ of deionized water. The solution was then heated to $85^{\circ} \mathrm{C}$ and held at this temperature for $5 \mathrm{~h}$. The resulting purple precipitate was filtered and washed with deionized water and ethanol. The precipitate was then calcined in static air at $500{ }^{\circ} \mathrm{C}$ for $5 \mathrm{~h}$ to obtain dehydrated cobalt molybdate. $\mathrm{Co}_{3} \mathrm{Mo}_{3} \mathrm{~N}$ was prepared by ammonolysis of $\mathrm{CoMoO}_{4}$ under $\mathrm{NH}_{3}$ (BOC, 99.98\%) at a flow rate of $100 \mathrm{~mL} \mathrm{~min}^{-1}$ at $785^{\circ} \mathrm{C}$ for $5 \mathrm{~h}$. The temperature was increased from ambient to $357{ }^{\circ} \mathrm{C}$ at $5.6{ }^{\circ} \mathrm{C} \mathrm{min}{ }^{-1}$, then after to $447{ }^{\circ} \mathrm{C} \mathrm{min}{ }^{-1}$ at $0.2{ }^{\circ} \mathrm{C} \mathrm{min}{ }^{-1}$ before being finally increased to $785^{\circ} \mathrm{C}$ at $2.1{ }^{\circ} \mathrm{C} \mathrm{min}{ }^{-1} . \mathrm{Co}_{3} \mathrm{Mo}_{3} \mathrm{C}$ was prepared by the carburization of $\mathrm{Co}_{3} \mathrm{Mo}_{3} \mathrm{~N}$ under 20 vol\% $\mathrm{CH}_{4}$ in $\mathrm{H}_{2}$ (BOC, 99.98\%) at a flow rate of $12 \mathrm{~mL} \mathrm{~min}^{-1}$ at $700{ }^{\circ} \mathrm{C}$ for $2 \mathrm{~h}$ with a ramp rate of $6{ }^{\circ} \mathrm{C} \mathrm{min}^{-1}$ to reach $350{ }^{\circ} \mathrm{C}$ followed by $1{ }^{\circ} \mathrm{C} \mathrm{min}{ }^{-1}$ to attain $700{ }^{\circ} \mathrm{C}$. $\mathrm{Co}_{6} \mathrm{Mo}_{6} \mathrm{C}$ was prepared by reducing $\mathrm{Co}_{3} \mathrm{Mo}_{3} \mathrm{C}$ at $900{ }^{\circ} \mathrm{C}$ for $5 \mathrm{~h}$ under $60 \mathrm{~mL} \mathrm{~min}^{-1}$ of a $75 \mathrm{vol} \% \mathrm{H}_{2}$ in $\mathrm{Ar}$ (BOC, 99.98\%) gas mixture.

\subsection{Materials Characterization}

X-ray diffraction patterns were collected on a Panalytical X'Pert PRO instrument, using $\mathrm{Cu} \mathrm{K} \alpha$ radiation $(\lambda=0.154 \mathrm{~nm})$ over a $2 \theta$ range of $5^{\circ}-85^{\circ}$, a step size of $0.0167^{\circ}$, and a counting time of $1 \mathrm{~s}$ per step. Samples were prepared by compaction into a $\mathrm{Si}$ sample holder. Phase identification was obtained by comparison with JCPDS database files. The surface areas of the samples were determined by application of the BET method to $\mathrm{N}_{2}$ physisorption isotherms collected at $-196{ }^{\circ} \mathrm{C}$ upon samples previously degassed at $110^{\circ} \mathrm{C}$ under vacuum for $12 \mathrm{~h}$. Scanning electron microscopy was performed on Philips XLSEM and FEI Quanta 200F Environmental instruments operating at $20 \mathrm{kV}$ for the investigation of morphology. Samples were coated with an $\mathrm{Au} / \mathrm{Pd}$ alloy prior to imaging. $\mathrm{CHN}$ analysis was undertaken by combustion using an Exeter Analytical CE-440 Elemental Analyzer. Thermogravimetric analysis (TGA) was carried out using a TA instruments QA instrument with measurements being undertaken in temperature range from room temperature to $1000{ }^{\circ} \mathrm{C}$ (ramp rate 10 degrees per minute) under a flow rate of $50 \mathrm{~mL} \mathrm{~min}^{-1}$ of air. Raman spectra of the samples were recorded at room temperature on a Horiba Jobin Yvon LabRam HR confocal Raman microscope, using a laser excitation of $523 \mathrm{~nm}$.

\subsection{Catalytic Activity Tests}

Methane cracking reactions were performed using $0.2 \mathrm{~g}$ of material which was placed in a quartz tube reactor under a gas feed of $12 \mathrm{~mL} \mathrm{~min}{ }^{-1}$ of a mixture of $75 \mathrm{vol} \% \mathrm{CH}_{4}$ in $\mathrm{N}_{2}$ (BOC, $99.98 \%$ ) at $800{ }^{\circ} \mathrm{C}$ for $8 \mathrm{~h}$ on stream. Hydrogen production was monitored by online gas chromatography (GC) using a TCD with Ar as carrier gas and employing a Molecular Sieve $13 \times$ column. The gas exhaust was also analysed in a periodic manner for the determination of $\mathrm{CO}_{x}$ by off-line FTIR analyses employing a gas-phase FTIR cell which could be isolated and by-passed for off-line analyses. FTIR spectra were recorded using a FTIR-8400S, Shimadzu apparatus. Each spectrum was collected at a spectral resolution of $2 \mathrm{~cm}^{-1}$, applying a scan range of $500-3500 \mathrm{~cm}^{-1}$.

\section{Results}

The structural and textural properties of the cobalt molybdenum based materials following the different nitridation and carburisation processes were monitored using a range of techniques. The results of the structural characterisation by XRD have been reported previously [16]. Powder XRD and neutron diffraction studies have confirmed the formation of 
high quality pure phases of $\mathrm{Co}_{3} \mathrm{Mo}_{3} \mathrm{C}, \mathrm{Co}_{6} \mathrm{Mo}_{6} \mathrm{C}, \mathrm{Co}_{3} \mathrm{Mo}_{3} \mathrm{~N}$ and $\mathrm{Co}_{6} \mathrm{Mo}_{6} \mathrm{~N}$. These results can be found in the Supplementary Information (Figs. S1, S2).

Raman spectra of the pre-reaction cobalt molybdenum materials are presented in Fig. 1. The Raman bands at 354, $806,866,930$ and $941 \mathrm{~cm}^{-1}$ are consistent with the presence of a surface cobalt molybdate phase [21] as might

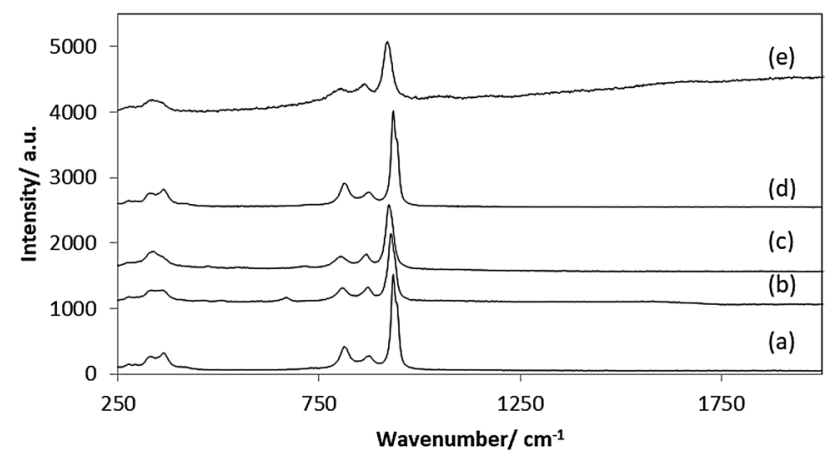

Fig. 1 Raman spectra of as prepared materials (a) $\mathrm{CoMoO}_{4},(b)$ $\mathrm{Co}_{3} \mathrm{Mo}_{3} \mathrm{~N},(c) \mathrm{Co}_{3} \mathrm{Mo}_{3} \mathrm{C},(d) \mathrm{Co}_{6} \mathrm{Mo}_{6} \mathrm{~N}$ and $(e) \mathrm{Co}_{6} \mathrm{Mo}_{6} \mathrm{C}$ be expected resulting from the presence of a surface passivation layer [22] for the carbide and nitride materials, which are known to be air-sensitive. Importantly, no Raman bands related to carbon deposition during the synthesis of $\mathrm{Co}_{3} \mathrm{Mo}_{3} \mathrm{C}$ and $\mathrm{Co}_{6} \mathrm{Mo}_{6} \mathrm{C}$ samples were observed which is consistent with the preparation of non-coked materials.

The SEM images presented in Fig. 2 demonstrate that all the materials prepared are pseudomorphic and exhibit a needle-like morphology as reported elsewhere [16]. The surface areas of the materials were determined to be 7, 18, 4 and $13 \mathrm{~m}^{2} \mathrm{~g}^{-1}$ for $\mathrm{CoMoO}_{4}, \mathrm{Co}_{3} \mathrm{Mo}_{3} \mathrm{~N}, \mathrm{Co}_{6} \mathrm{Mo}_{6} \mathrm{~N}$ and $\mathrm{Co}_{3} \mathrm{Mo}_{3} \mathrm{C}$ respectively (Table 1 ). The lower surface area of the $\mathrm{Co}_{6} \mathrm{Mo}_{6} \mathrm{C}$ phase $\left(\sim 3 \mathrm{~m}^{2} \mathrm{~g}^{-1}\right)$, can be attributed to the higher reaction temperature applied in its preparation.

The role of the nature of the stoichiometry and also the interstitial element present in the catalytic methane cracking activity of cobalt molybdenum materials was investigated by comparing the activity of the $\mathrm{Co}_{3} \mathrm{Mo}_{3} \mathrm{C}$ and $\mathrm{Co}_{6} \mathrm{Mo}_{6} \mathrm{C}$ to $\mathrm{Co}_{3} \mathrm{Mo}_{3} \mathrm{~N}$ and $\mathrm{Co}_{6} \mathrm{Mo}_{6} \mathrm{~N}$ materials. The reaction profiles illustrating the evolution of the mass normalised hydrogen formation rate as a function of time on stream is presented Fig. 3. Although, all materials displayed activity
Fig. 2 SEM images of as prepared materials: $\mathbf{a} \mathrm{Co}_{3} \mathrm{Mo}_{3} \mathrm{~N}$, b $\mathrm{Co}_{3} \mathrm{Mo}_{3} \mathrm{C}, \mathbf{c ~} \mathrm{Co}_{6} \mathrm{Mo}_{6} \mathrm{~N}$ and $\mathbf{d}$ $\mathrm{Co}_{6} \mathrm{Mo}_{6} \mathrm{C}$
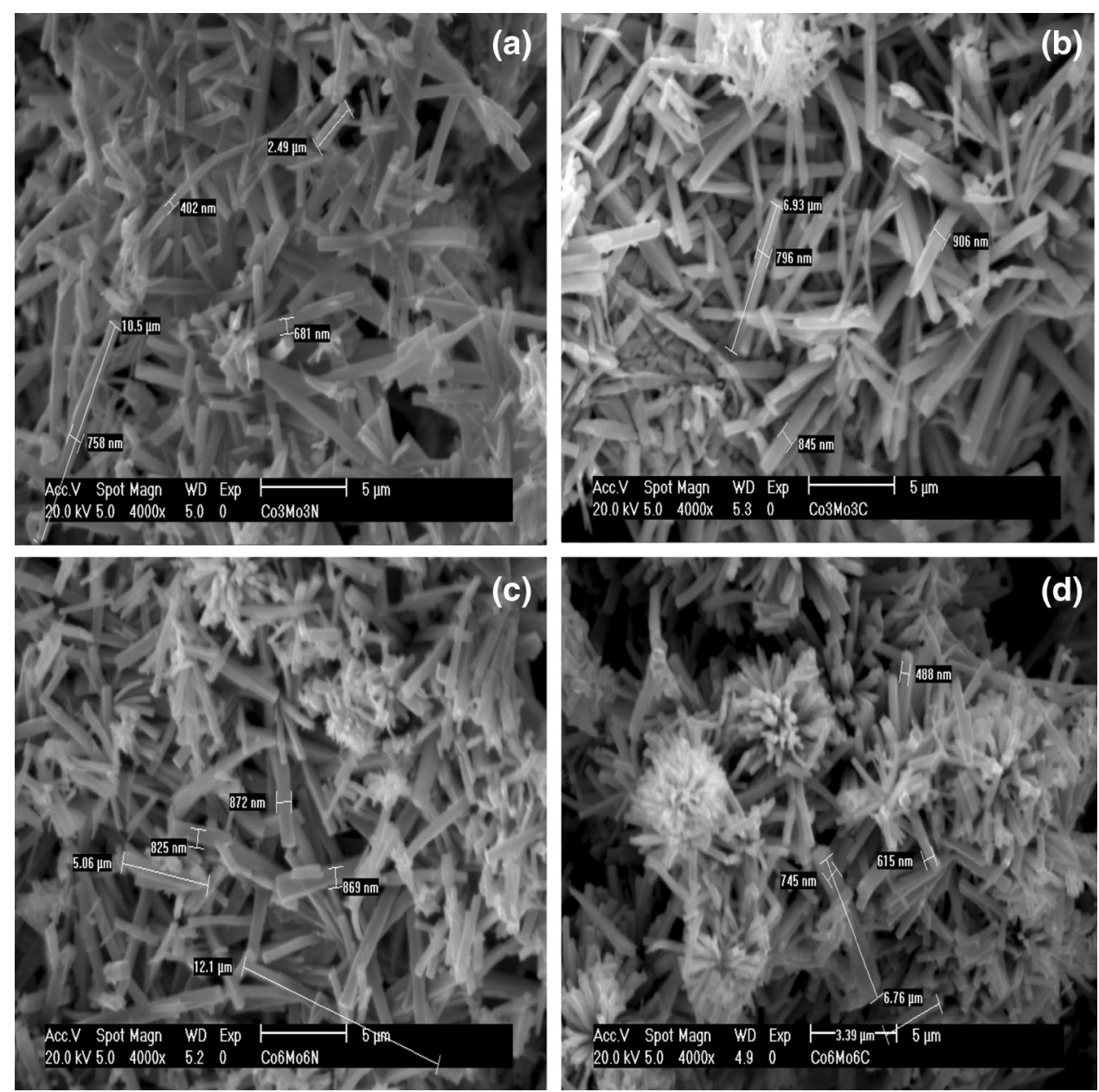
Table 1 Summary of the textural and structural characterisation of post-reaction catalysts

\begin{tabular}{|c|c|c|c|c|c|c|c|}
\hline & \multirow[t]{2}{*}{ Post-reaction XRD phase } & \multicolumn{2}{|c|}{ Nitrogen content $\mathrm{a} / \mathrm{wt} \%$} & \multicolumn{2}{|c|}{ Carbon content $\mathrm{a} / \mathrm{wt} \%$} & \multicolumn{2}{|l|}{$\mathrm{S}_{\mathrm{BET}}^{\mathrm{b}} / \mathrm{m}^{2} \mathrm{~g}^{-1}$} \\
\hline & & As-prepared & Post-reaction & As-prepared & Post-reaction & As prepared & Post-reaction \\
\hline $\mathrm{CoMoO}_{4}$ & $\begin{array}{l}\text { Graphite (003-0401), } \beta-\mathrm{Mo}_{2} \mathrm{C}(001-1188) \text {, } \\
\quad \alpha-\mathrm{Co}(01-089-7093)\end{array}$ & - & N.d. & - & $71 \pm 1$ & 7 & 31 \\
\hline $\mathrm{Co}_{3} \mathrm{Mo}_{3} \mathrm{~N}$ & $\begin{array}{l}\mathrm{Co}_{3} \mathrm{Mo}_{3} \mathrm{C}(03-065-7128), \text { graphite }(003- \\
0401), \beta-\mathrm{Mo}_{2} \mathrm{C}(001-1188), \alpha-\mathrm{Co}(01-089- \\
7093)\end{array}$ & $3.0 \pm 0.1 \mathrm{~N}$ & N.d. & - & $85 \pm 3$ & 18 & 63 \\
\hline $\mathrm{Co}_{3} \mathrm{Mo}_{3} \mathrm{C}$ & $\begin{array}{l}\mathrm{Co}_{3} \mathrm{Mo}_{3} \mathrm{C}(03-065-7128) \text {, graphite (003- } \\
0401), \beta-\mathrm{Mo}_{2} \mathrm{C}(001-1188), \alpha-\mathrm{Co}(01-089- \\
7093)\end{array}$ & - & N.d. & $2.5 \pm 0.1$ & $84 \pm 1$ & 13 & 50 \\
\hline $\mathrm{Co}_{6} \mathrm{Mo}_{6} \mathrm{~N}$ & $\begin{array}{l}\mathrm{Co}_{3} \mathrm{Mo}_{3} \mathrm{C}(03-065-7128), \text { graphite }(003- \\
0401), \beta-\mathrm{Mo}_{2} \mathrm{C}(001-1188), \alpha-\mathrm{Co}(01-089- \\
7093)\end{array}$ & $1.6 \pm 0.1 \mathrm{~N}$ & N.d. & - & $84 \pm 1$ & 4 & 59 \\
\hline $\mathrm{Co}_{6} \mathrm{Mo}_{6} \mathrm{C}$ & $\begin{array}{l}\mathrm{Co}_{3} \mathrm{Mo}_{3} \mathrm{C}(03-065-7128), \text { graphite }(003- \\
0401)\end{array}$ & - & N.d. & $1.3 \pm 0.1$ & $69 \pm 1$ & 3 & 24 \\
\hline
\end{tabular}

N.d. not detected

${ }^{a}$ Nitrogen analysis undertaken using an Exeter Analytical CE-440 Elemental Analyser

${ }^{\mathrm{b}} \mathrm{S}_{\mathrm{BET}}$ is the specific surface area evaluated using the BET model

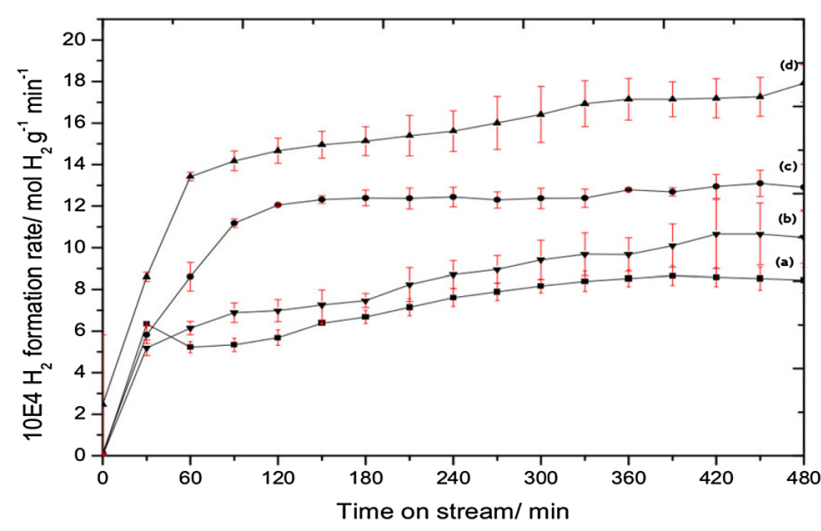

Fig. 3 Hydrogen formation rates as a function of time on stream for methane cracking over $(a) \mathrm{CoMoO}_{4},(b) \mathrm{Co}_{6} \mathrm{Mo}_{6} \mathrm{C},(c) \mathrm{Co}_{3} \mathrm{Mo}_{3} \mathrm{~N}$ and (d) $\mathrm{Co}_{6} \mathrm{Mo}_{6} \mathrm{~N}$ at $800{ }^{\circ} \mathrm{C}$

for hydrogen production, clear differences in the hydrogen formation rates are observed. Hydrogen production tended to reach a plateau after $120 \mathrm{~min}$ on stream. However, in the case of the $\mathrm{Co}_{3} \mathrm{Mo}_{3} \mathrm{C}$ sample, less reproducible behaviour occurred, which was possibly related to carbon build-up during the reaction resulting in reactor blockage. Similar observations were witnessed upon repeating the experiment and the structural and textural properties of the post-reaction samples were all similar (Fig. S3). Due to the fact that the performance of $\mathrm{Co}_{3} \mathrm{Mo}_{3} \mathrm{C}$ is less reproducible, its reaction profile is not presented in Fig. 3 but is instead shown in Fig. S2.

In the presence of $\mathrm{N}_{2}$ and $\mathrm{H}_{2}$, as is the case in this study, $\mathrm{Co}_{3} \mathrm{Mo}_{3} \mathrm{~N}$ and $\mathrm{Co}_{3} \mathrm{Mo}_{3} \mathrm{C}$ have been reported to be active catalytic systems for ammonia generation at ambient pressure

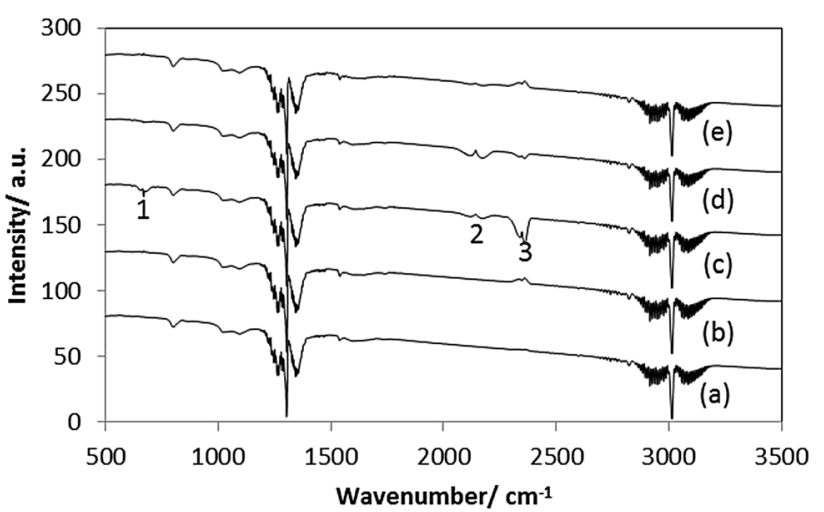

Fig. 4 FTIR analyses of gas-phase products from $\mathrm{CoMoO}_{4}$ reacted with $\mathrm{CH}_{4} / \mathrm{N}_{2}$ (a) the feed gas, (b) $800{ }^{\circ} \mathrm{C}$, (c) $800{ }^{\circ} \mathrm{C} 20 \mathrm{~min},(d)$ $800{ }^{\circ} \mathrm{C} 50 \mathrm{~min}$, and $(e) 800{ }^{\circ} \mathrm{C} 60 \mathrm{~min}$. Bands 1 and 3 are related to gas-phase $\mathrm{CO}_{2}$ whereas band is 2 related to gas-phase $\mathrm{CO}$

[16]. However, the reaction is thermodynamically unfavourable at high temperature and ammonia content at equilibrium is $\sim 0.001 \mathrm{~mol} \%$ at ca. $800{ }^{\circ} \mathrm{C}$. Thus, the consumption of hydrogen to generate ammonia by reaction with the $\mathrm{N}_{2}$ internal standard within the methane feed under these conditions can be safely ruled out.

In the case of cobalt molybdenum nitride and carbides, off-line FTIR spectra recorded periodically during reaction showed that the production of $\mathrm{CO}$ and $\mathrm{CO}_{2}$ during methane cracking was below the detection limit. However, as might be expected, $\mathrm{CO}$ and $\mathrm{CO}_{2}$ were clearly observed when $\mathrm{CoMoO}_{4}$ was used as a catalyst (Fig. 4). FTIR analysis of gas products from this sample shows after $20 \mathrm{~min}$ of reaction, bands at 660 and $2360 \mathrm{~cm}^{-1}$ which can be related to 
$\mathrm{CO}_{2}$ and at $2177 \mathrm{~cm}^{-1}$ which is assigned to $\mathrm{CO}$. However, the production of $\mathrm{CO}$ and $\mathrm{CO}_{2}$ ceased after 50 min of reaction. It is noteworthy that the production of $\mathrm{CO}$, even in small concentrations, can be harmful in the case of some

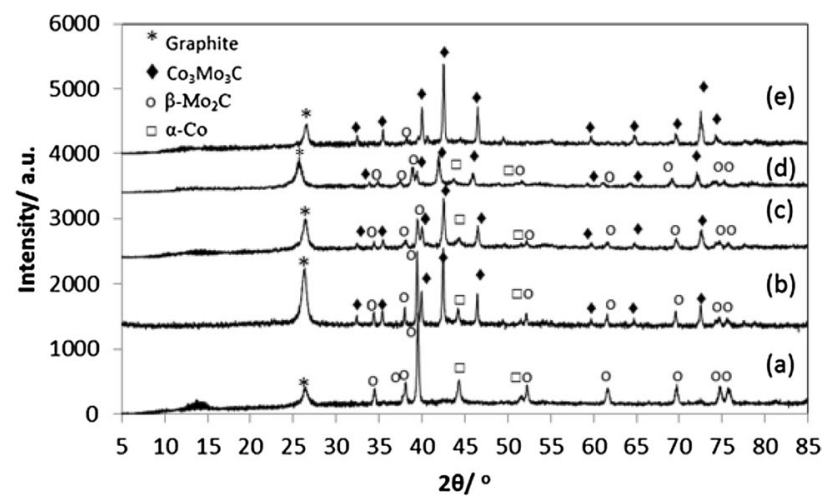

Fig. 5 Powder X-ray diffraction patterns of the post-reaction: (a) $\mathrm{CoMoO}_{4},(b) \mathrm{Co}_{3} \mathrm{Mo}_{3} \mathrm{~N},(c) \mathrm{Co}_{3} \mathrm{Mo}_{3} \mathrm{C},(d) \mathrm{Co}_{6} \mathrm{Mo}_{6} \mathrm{~N}$ and (e) $\mathrm{Co}_{6} \mathrm{Mo}_{6} \mathrm{C}$ materials. Diamond: $\mathrm{Co}_{3} \mathrm{Mo}_{3} \mathrm{C}$ (03-065-7128), asterisk: graphite (003-0401), open circle: $\beta-\mathrm{Mo}_{2} \mathrm{C}$ (001-1188), open square: $\alpha$-Co (01-089-7093) downstream applications such as the use of $\mathrm{H}_{2}$ in PEM fuel cells $[23,24]$. The results presented herein suggest, beyond the initial loss of the surface passivation layer upon reaction, the use of cobalt molybdenum nitrides or carbides might be suitable for the production of $\mathrm{CO}_{\mathrm{x}}$-free hydrogen from methane cracking for such applications.

The characterisation of the post-reaction materials is presented in Figs. 5, 6, 7, 8 and 9 and in Table 1. Figure 5 presents the post-reaction powder XRD patterns. The XRD results are consistent with the formation of graphite as expected. In addition, a number of significant phase transformations to the original materials have occurred upon reaction (Fig. 5; Table 1). In most cases, $\mathrm{Co}_{3} \mathrm{Mo}_{3} \mathrm{C}$ appeared to be the predominant phase, although the formation of some $\beta-\mathrm{Mo}_{2} \mathrm{C}$ and $\alpha-\mathrm{Co}$ is also apparent. However, interestingly, in the case of $\mathrm{CoMoO}_{4}$, only $\beta-\mathrm{Mo}_{2} \mathrm{C}, \alpha-\mathrm{Co}$ and graphite were evident after reaction with the ternary carbide phase being absent.

As shown in Fig. 6, morphological changes also occurred upon reaction. The agglomerated needle-like morphology was transformed to agglomerated block like structures. In contrast, post-reaction $\mathrm{Co}_{6} \mathrm{Mo}_{6} \mathrm{C}$ appeared to
Fig. 6 SEM post-reaction images of: $\mathbf{a ~} \mathrm{Co}_{3} \mathrm{Mo}_{3} \mathrm{~N}$, b $\mathrm{Co}_{3} \mathrm{Mo}_{3} \mathrm{C}, \mathbf{c ~} \mathrm{Co}_{6} \mathrm{Mo}_{6} \mathrm{~N}$ and $\mathbf{d}$ $\mathrm{Co}_{6} \mathrm{Mo}_{6} \mathrm{C}$
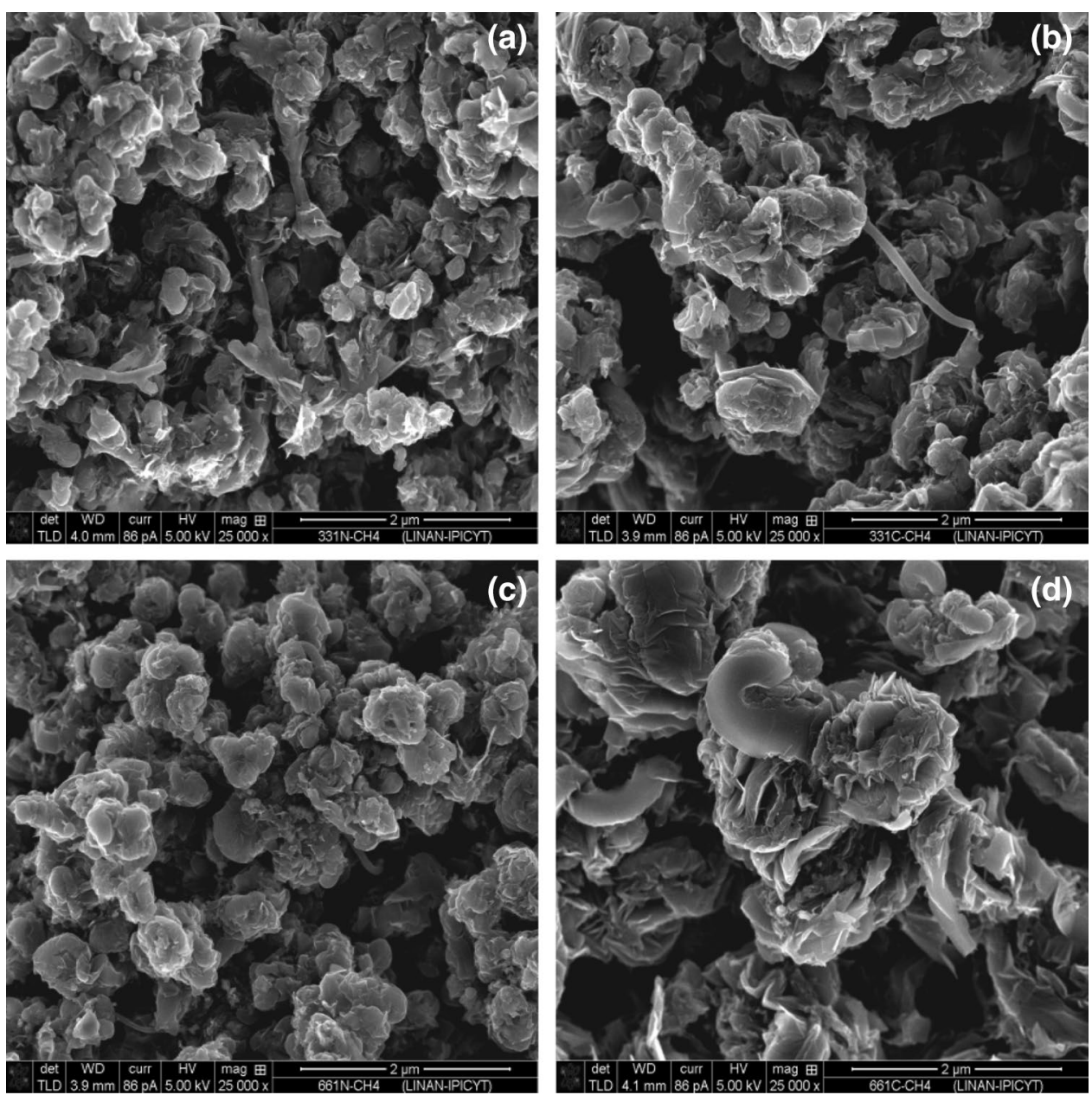


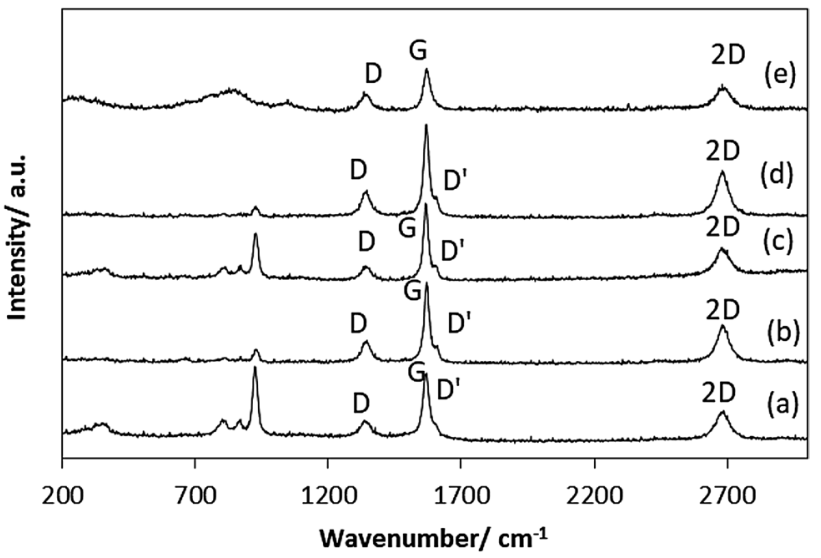

Fig. 7 Raman spectra of the post-reaction materials $(a) \mathrm{CoMoO}_{4},(b)$ $\mathrm{Co}_{3} \mathrm{Mo}_{3} \mathrm{~N},(c) \mathrm{Co}_{3} \mathrm{Mo}_{3} \mathrm{C},(d) \mathrm{Co}_{6} \mathrm{Mo}_{6} \mathrm{~N}$ and $(e) \mathrm{Co}_{6} \mathrm{Mo}_{6} \mathrm{C}$

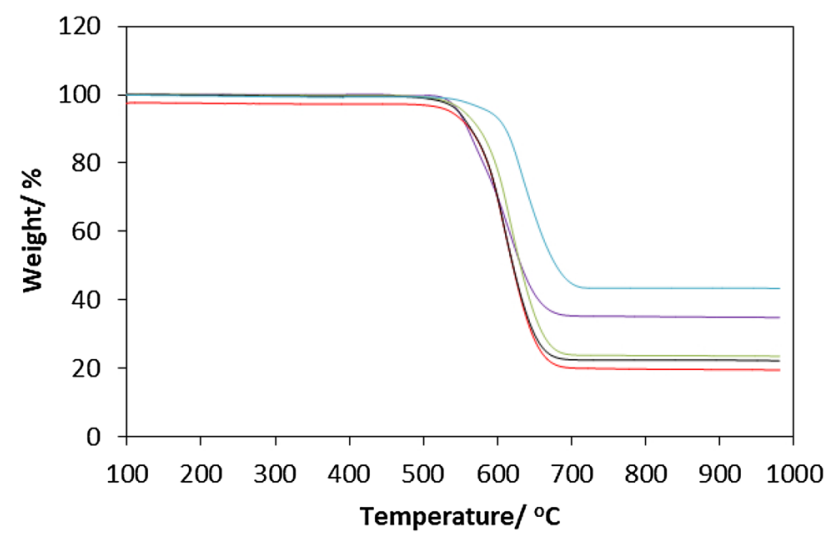

Fig. 8 TGA traces under air for post-reaction materials: (purple) $\mathrm{CoMoO}_{4}$, (red) $\mathrm{Co}_{3} \mathrm{Mo}_{3} \mathrm{~N}$, (green) $\mathrm{Co}_{3} \mathrm{Mo}_{3} \mathrm{C}$, (black) $\mathrm{Co}_{6} \mathrm{Mo}_{6} \mathrm{~N}$ and (blue) $\mathrm{Co}_{6} \mathrm{Mo}_{6} \mathrm{C}$

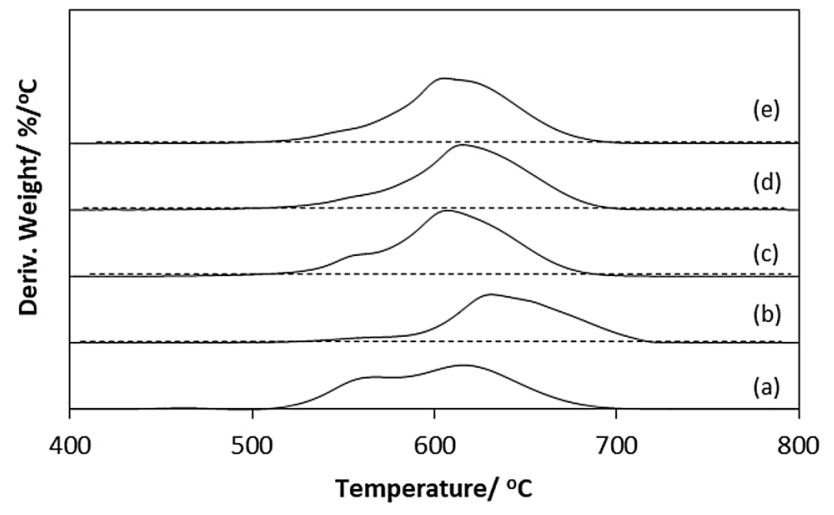

Fig. 9 Derivative weight curves for post-reaction materials under air (a) $\mathrm{CoMoO}_{4},(b) \mathrm{Co}_{3} \mathrm{Mo}_{3} \mathrm{~N},(c) \mathrm{Co}_{3} \mathrm{Mo}_{3} \mathrm{C},(d) \mathrm{Co}_{6} \mathrm{Mo}_{6} \mathrm{~N}$ and $(e)$ $\mathrm{Co}_{6} \mathrm{Mo}_{6} \mathrm{C}$ exhibit larger particle sizes compared to its post-reaction $\mathrm{Co}_{3} \mathrm{Mo}_{3} \mathrm{~N}, \mathrm{Co}_{3} \mathrm{Mo}_{3} \mathrm{C}$ and $\mathrm{Co}_{6} \mathrm{Mo}_{6} \mathrm{~N}$ counterparts within the statistical limitations of the observations made. It is also interesting to note that in general, post-reaction catalyst displayed a higher surface area than pre-reaction materials. Both the drastic change in morphology and the enhanced surface area can be, at least partly, attributed to the significant deposition of carbon as a result of reaction. The comparatively lower surface area evident in the case of $\mathrm{Co}_{6} \mathrm{Mo}_{6} \mathrm{C}$ is in accordance with the large particle size observed for this sample by SEM.

The $\mathrm{CoMoO}_{4}$ and $\mathrm{Co}_{6} \mathrm{Mo}_{6} \mathrm{C}$ post-reaction samples were found to contain $\sim 70 \mathrm{wt} \% \mathrm{C}$ (Table 1), with a higher postreaction carbon content $\left(\sim 84 \mathrm{wt} \% \mathrm{C}\right.$ ) evident for $\mathrm{Co}_{3} \mathrm{Mo}_{3} \mathrm{C}$, $\mathrm{Co}_{3} \mathrm{Mo}_{3} \mathrm{~N}$ and $\mathrm{Co}_{6} \mathrm{Mo}_{6} \mathrm{~N}$ as would be anticipated from their higher hydrogen formation rates. The nature of the carbonaceous species deposited was characterized by Raman spectroscopy. Post-reaction Raman spectra, presented in Fig. 7, provide strong evidence of the presence of disordered and graphitic carbon with Raman bands observed at 1350 and $1582 \mathrm{~cm}^{-1}$ labelled (D) and (G) respectively [25]. An additional band, of lower intensity, at $1620 \mathrm{~cm}^{-1}$ labelled as $\mathrm{D}^{\prime}$ was observed for the $\mathrm{Co}_{3} \mathrm{Mo}_{3} \mathrm{~N}, \mathrm{Co}_{3} \mathrm{Mo}_{3} \mathrm{C}$ and $\mathrm{Co}_{6} \mathrm{Mo}_{6} \mathrm{~N}$ samples. In the literature, several explanations exist and the additional band can be correlated in principle to the presence of a high concentration of defects [26-28]. Additional Raman bands related to cobalt molybdate were detected in the post-reaction $\mathrm{CoMoO}_{4}$ and post-reaction $\mathrm{Co}_{3} \mathrm{Mo}_{3} \mathrm{C}$.

To further characterise the nature of the carbon deposit after reaction, TGA in air was carried out over the temperature range $100-1000{ }^{\circ} \mathrm{C}$ (Fig. 8). It was observed that the carbon oxidation started for all materials from $500{ }^{\circ} \mathrm{C}$ and was complete by $700{ }^{\circ} \mathrm{C}$. Beyond, this point no further change in the weight of the material was observed. The total weight loss was between 60 and $80 \mathrm{wt} \%$ which accords well with the results of post-reaction elemental analysis (Table 1). The first derivative profiles for the different post-reaction materials are presented in Fig. 9. In all materials, two weight loss regions have been observed. The first weight loss peak is observed in the temperature range between 500 and $600{ }^{\circ} \mathrm{C}$ while the second weight loss peak is observed at higher temperatures $\left(600-700{ }^{\circ} \mathrm{C}\right)$. The contribution of the first peak was particularly significant in the post-reaction $\mathrm{CoMoO}_{4}$ material and to some extent in the $\mathrm{Co}_{3} \mathrm{Mo}_{3} \mathrm{C}$. However, the oxidation of carbon in $\mathrm{Co}_{3} \mathrm{Mo}_{3} \mathrm{~N}, \mathrm{Co}_{6} \mathrm{Mo}_{6} \mathrm{~N}$ and $\mathrm{Co}_{6} \mathrm{Mo}_{6} \mathrm{C}$ materials occurred mainly at temperature ranging between 600 and $700{ }^{\circ} \mathrm{C}$. The contrast between the two oxidation regions could suggest the presence of two forms of carbon. However, the presence of the oxide phase, as evidenced in their Raman spectra, in the case of post-reaction $\mathrm{CoMoO}_{4}$ and post-reaction $\mathrm{Co}_{3} \mathrm{Mo}_{3} \mathrm{C}$ as observed by Raman spectra (Fig. 7) may have enhanced the oxidation of carbon at low temperature. 


\section{Discussion}

The topotactic transformation pathways and pseudomorphic nature of the cobalt molybdenum carbide and nitride families evident in this study offers, in principle, an elegant route to study the effect of interstitial carbon/nitrogen on the catalytic activity of cobalt molybdenum materials for methane cracking. All the prepared materials possess activity for hydrogen production at $800^{\circ} \mathrm{C}$. Interestingly, the catalytic activity of these materials varied depending upon initial composition with $\mathrm{Co}_{6} \mathrm{Mo}_{6} \mathrm{~N}$ being the most active (Fig. 3). The activity of the material was found to stabilise around $1.8 \mathrm{mmol} \mathrm{H}_{2} \mathrm{~g}_{\text {catalyst }}{ }^{-1} \mathrm{~min}^{-1}$, which is high when compared against the activity of some other nitride systems (e.g. $180 \mu \mathrm{mol} \mathrm{H} \mathrm{g}_{\text {catalyst }}{ }^{-1}$ min reported for a silicon-vanadium nitride nanocomposite under directly comparable conditions) [29]. In fact, the activity of the $\mathrm{Co}_{6} \mathrm{Mo}_{6} \mathrm{~N}$ is directly comparable to the activity of iron oxide (for which a rate of $1 \mathrm{mmol} \mathrm{H}_{2} \mathrm{~g}_{\text {catalyst }}{ }^{-1}$ $\min ^{-1}$ was previously reported for iron oxide under the same reaction conditions) [30]. In general, the activity of the carbides and nitrides presented a normalised hydrogen production rate ranging from 1.1 to $1.8 \mathrm{mmol} \mathrm{H}_{2} \mathrm{~g}_{\text {catalyst }}{ }^{-1}$ $\mathrm{min}^{-1}$. A slightly lower activity $\left(0.8 \mathrm{mmol} \mathrm{H}_{2} \mathrm{~g}_{\text {catalyst }}{ }^{-1}\right.$ $\mathrm{min}^{-1}$ ) was found for the $\mathrm{CoMoO}_{4}$ system. In addition to the relatively enhanced activity of the cobalt molybdenum carbide and nitride systems when compared to the oxide counterpart, the absence of significant production of $\mathrm{CO}_{\mathrm{x}}$, beyond that which might be expected from conversion of the surface passivation layer, during the methane cracking reaction is of potential interest in relation to free of $\mathrm{CO}_{\mathrm{x}}-\mathrm{H}_{2}$ production.

As expected, the production of $\mathrm{H}_{2}$ was accompanied by carbon deposition. Due to the nature of the reaction, the amount of carbon deposited on carbide and nitride systems can be correlated directly to the activity of methane cracking as expected. Elemental analysis showed significant deposition of carbon $\sim 85 \mathrm{wt} \%$ on $\mathrm{Co}_{3} \mathrm{Mo}_{3} \mathrm{~N}, \mathrm{Co}_{3} \mathrm{Mo}_{3} \mathrm{C}$ and $\mathrm{Co}_{6} \mathrm{Mo}_{6} \mathrm{~N}$ confirming the high activity of these materials, in spite of the less reproducible hydrogen production behaviour of $\mathrm{Co}_{3} \mathrm{Mo}_{3} \mathrm{C}$. Thermogravimetric analyses conducted under air confirmed that the weight loss associated with carbon oxidation to be consistent with the elemental analyses of post-reaction materials. The nature of the carbon present upon reaction has been investigated by Raman spectroscopy (Fig. 7). The Raman futures were dominated by the presence of two forms of carbon: disordered and graphitic carbon. The existence of several forms of carbon was also evident from the derivative weight curves for post-reaction samples.

While it is tempting to discuss the activity of the catalysts against their initial composition, post-reaction analysis revealed changes in the structural properties upon reaction. As might be expected under the reaction conditions applied, post-reaction powder XRD (Fig. 5), showed the carburisation of all the materials studied when reacted. However, the products of carburisation slightly differ depending on the initial composition. In the postreaction $\mathrm{CoMoO}_{4}$, only $\beta-\mathrm{Mo}_{2} \mathrm{C}(001-1188)$ and $\alpha$-Co (01089-7093) are observed as a result of the carburisation of $\mathrm{CoMoO}_{4}$ as well as graphite generated from methane cracking. However, a mixture of $\mathrm{Co}_{3} \mathrm{Mo}_{3} \mathrm{C}$ (03-065-7128), $\alpha$-Co (01-089-7093) and $\beta-\mathrm{Mo}_{2} \mathrm{C}(001-1188)$ is detected upon reaction of $\mathrm{Co}_{3} \mathrm{Mo}_{3} \mathrm{~N}, \mathrm{Co}_{3} \mathrm{Mo}_{3} \mathrm{C}$ and $\mathrm{Co}_{6} \mathrm{Mo}_{6} \mathrm{~N}$ with methane. In the case of $\mathrm{Co}_{6} \mathrm{Mo}_{6} \mathrm{C}$ relocation of the carbon located in the $8 \mathrm{a}\left(\begin{array}{lll}0 & 0 & 0\end{array}\right)$ Wyckoff site to the $16 \mathrm{c}(1 / 81 / 8$ 1/8) site occurs associated with the formation of $\mathrm{Co}_{3} \mathrm{Mo}_{3} \mathrm{C}$ without clear evidence of the formation of $\beta-\mathrm{Mo}_{2} \mathrm{C}$ and $\alpha$-Co [01-089-7093 (001-1188)] phases as observed in the previous cases.

In summary, for the three most active catalysts, the phases detected after reaction comprised a mixture of $\mathrm{Co}_{3} \mathrm{Mo}_{3} \mathrm{C}$ (03-065-7128), $\alpha$-Co (01-089-7093) and $\beta-\mathrm{Mo}_{2} \mathrm{C}(001-$ 1188). While, for the least active material $\mathrm{CoMoO}_{4}$, only the $\beta-\mathrm{Mo}_{2} \mathrm{C}$ and $\alpha-\mathrm{Co}$ (01-089-7093) were detected. Another major aspect, where differences are potentially evident, is the accessible surface area of the active phases. The surface area measured in post-reaction $\mathrm{Co}_{3} \mathrm{Mo}_{3} \mathrm{~N}, \mathrm{Co}_{3} \mathrm{Mo}_{3} \mathrm{C}$ and $\mathrm{Co}_{6} \mathrm{Mo}_{6} \mathrm{~N}$ samples ranged between 50 and $63 \mathrm{~m}^{2} \mathrm{~g}^{-1}$ while in the case of $\mathrm{CoMoO}_{4}$ and $\mathrm{Co}_{6} \mathrm{Mo}_{6} \mathrm{C}$ the surface area was limited to $\sim 30 \mathrm{~m}^{2} \mathrm{~g}^{-1}$. Despite the fact that no simple link can be established between the catalytic activity to phase composition and accessible surface area, it can be argued that the presence of $\mathrm{Co}_{3} \mathrm{Mo}_{3} \mathrm{C}, \alpha-\mathrm{Co}$ and $\beta-\mathrm{Mo}_{2} \mathrm{C}$ and high surface area leads to an enhanced activity for methane cracking. In addition, the initial composition seems to play an important role in the final activity of the catalysts. These differences may indicate differences in the active surface composition resulting from the carburisation process of different cobalt molybdenum precursors. Further characterisation of the carburisation process of cobalt molybdenum materials by in-situ neutron diffraction, in condition of relevance to this study, are currently under investigation and will bring new insight to the process. Elsewhere, cobalt-molybdenum oxycarbide surface phases have been proposed to be of importance for activity and lifetime [31].

\section{Conclusion}

A range of cobalt molybdenum containg materials have been prepared and tested as catalysts for the production of hydrogen from methane at $800{ }^{\circ} \mathrm{C}$. After a short induction period, all samples were active and stable for the generation of hydrogen over the period tested, with the exception of 
$\mathrm{Co}_{3} \mathrm{Mo}_{3} \mathrm{C}$. Amongst the evaluated materials, the $\mathrm{Co}_{6} \mathrm{Mo}_{6} \mathrm{~N}$ sample showed the highest activity of about $1.8 \mathrm{mmol} \mathrm{H}_{2}$ $\mathrm{g}^{-1} \mathrm{~min}^{-1}$, comparable to those observed for iron oxide systems under similar reaction conditions. The results revealed that a significant phase transformation from metal nitrides to $\mathrm{Co}_{3} \mathrm{Mo}_{3} \mathrm{C}$ and $\beta-\mathrm{Mo}_{2} \mathrm{C}$ occurred throughout the methane cracking reaction. Interestingly, in the case of $\mathrm{Co}_{6} \mathrm{Mo}_{6} \mathrm{C}$ relocation of the carbon located in the $000(8 \mathrm{a})$ site to $1 / 8$ $1 / 81 / 8$ (16c) sites resulting in the formation of $\mathrm{Co}_{3} \mathrm{Mo}_{3} \mathrm{C}$ was observed. Furthermore, results from Raman spectroscopy and powder XRD show that at least two forms of carbon are formed on the catalyst surface during methane decomposition.

Acknowledgements We are grateful to Mr M. G. Reddy form the University of Glasgow for conducting elemental analyses. JSJH wishes to acknowledge the Engineering and Physical Sciences Research Council for support through grant EP/L02537X/1. JLR is grateful to Conacyt for funding a sabbatical stay at the University of Glasgow and to LINAN-IPICYT for electron microscope facilities.

\section{Compliance with Ethical Standards}

Conflict of interest The authors declare no conflict of interest.

Open Access This article is distributed under the terms of the Creative Commons Attribution 4.0 International License (http://creativeco mmons.org/licenses/by/4.0/), which permits unrestricted use, distribution, and reproduction in any medium, provided you give appropriate credit to the original author(s) and the source, provide a link to the Creative Commons license, and indicate if changes were made.

\section{References}

1. Alexander AM, Hargreaves JSJ (2010) Chem Soc Rev 39(11):4388

2. Hargreaves JSJ (2013) Coord Chem Rev 257:(13-14) 2015

3. Hargreaves JSJ, McFarlane AR, Laassiri S (eds) (2018) Alternative catalytic materials: carbides, nitrides, phosphides and amorphous boron alloys. RSC, London

4. Levy RB, Boudart M (1973) Science 181:547

5. Oyama ST (1992) Catal Today $15: 179$

6. Weller S, Hofer LJE, Anderson RB (1948) J Am Chem Soc 70(2):799
7. Ordomsky VV, Legras B, Cheng K, Paul S, Khodakov AY (2015) Catal Sci Technol 5(3):1433

8. Vo D-VN, Adesina AA (2011) Chap. 7: evaluation of promoted Mo carbide catalysts for Fischer-Tropsch synthesis: synthesis, characterisation, and time-on-stream behaviour. In: de Klerk A, King DL (eds) Synthetic liquids production and refining, vol 1084. ACS, Washington, DC, pp 155-184

9. Ranhotra GS, Bell AT, Reimer JA (1987) J Catal 108(1):40

10. Kojima I, Miyazaki E, Inoue Y, Yasumori I (1982) J Catal 73(1): 128

11. Lee JS, Yeom MH, Park KY, Nam I-S, Chung JS, Kim YG, Moon SH (1991) J Catal 128(1):126

12. Perret N, Wang X, Delannoy L, Potvin C, Louis C, Keane MA (2012) J Catal 286:172

13. Jiang J, Liu Q, Zeng C, Ai L (2017) J Mater Chem A 5(32):16929

14. Choi J-G (1999) J Catal 182(1):104

15. Pansare SS, Torres W, Goodwin JG (2007) Catal Commun 8(4):649

16. AlShibane I, Daisley A, Hargreaves JSJ, Hector AL, Laassiri S, Rico JL, Smith RI (2017) ACS Sustain Chem Eng 5(10):9214

17. Abbas HF, Wan Daud WMA (2010) Int J Hydrogen Energy 35(3): 1160

18. Li Y, Li D, Wang G (2011) Catal Today 162(1):1

19. Amin AM, Croiset E, Epling W (2011) Int J Hydrogen Energy 36(4):2904

20. Hunter SM, McKay D, Smith RI, Hargreaves JSJ, Gregory DH (2010) Chem Mater 22(9):2898

21. Xu K, Chao J, Li W, Liu Q, Wang Z, Liu X, Zou R, Hu J (2014) RSC Adv 4(65):34307

22. Alconchel S, Sapina F, Martinez E (2004) Dalton Trans (16:):2463

23. Schmittinger W, Vahidi A (2008) J Power Sources 180(1):1

24. Choudhary TV, Aksoylu E, Goodman DW (2003) Nonoxidative activation of methane. Catal Rev 45(1):151

25. Gupta A, Chen G, Joshi P, Tadigadapa S, Eklund (2006) Nano Lett 6(12):2667

26. Cançado LG, Pimenta MA, Neves BRA, Dantas MSS, Jorio A (2004) Phy Rev Lett 93(24):247401

27. Kudin KN, Ozbas B, Schniepp HC, Prud'homme RK, Aksay IA, Car R (2008) Nano Lett 8(1):36

28. Livneh T, Haslett TL, Moskovits M (2002) Phy Rev B 66(19): 195110

29. AlShibane I, Hargreaves JSJ, Hector AL, Levason W, McFarlane A (2017) Dalton Trans 46(27):8782

30. Alharthi A, Blackley RA, Flowers TH, Hargreaves JSJ, Pulford ID, Wigzell J, Zhou W (2014) J Chem Technol Biotechnol 89(9): 1317

31. Izhar S, Kanesugi H, Tominaga H, Nagai M (2007) Appl Catal A: Gen 317:82 